\title{
Toxicity reduction evaluation (TRE) procedure for identification of toxic substances in landfill leachate
}

\author{
M. Cotman ${ }^{1}$ \& A. Žgajnar-Gotvajn ${ }^{2}$ \\ ${ }^{\prime}$ National Institute of Chemistry, Slovenia \\ ${ }^{2}$ University of Ljubljana, Faculty of Chemistry and Chemical Technology, \\ Slovenia
}

\begin{abstract}
Landfilling is one of the most widely used methods for the disposal of municipal solid wastes. The degradation of the organic fraction of the wastes in combination with percolating rainwater leads to the generation of highly contaminated liquid, called leachate. Municipal landfill leachates typically contain high concentrations of inorganic compounds (ammonium and metals), as well as high levels of organics, many of them also toxic and resistant to biodegradation. Because of this, treatment efficiency of conventional biological plant for landfill leachates is usually very low. The purpose of our research work was to evaluate the quality of the leachate originating from municipal landfill and to assess efficiency of air stripping and adsorption to activated carbon for reduction of toxicity of the leachate. Both TRE procedures were used to identify the contribution of organic substances (air stripping, adsorption) and ammonium nitrogen (air stripping) to toxicity of the effluent. We have followed the efficiency of single toxicity reduction method with measurement of physicochemical parameters and toxicity bioassays. They were carried out by applying an acute toxicity test with luminiscent bacteria Vibrio fischeri and an acute test with nitrifying microorganisms from activated sludge.

We have compared physico-chemical analysis and toxicity of the leachate before and after TRE procedures. Air stripping removed $85 \%$ of ammonium nitrogen at $\mathrm{pH}$ value of 11 , but the removal of organics was low. On the other hand, adsorption to activated carbon $\left(50 \mathrm{~g} \cdot \mathrm{L}^{-1}\right)$ removed $79 \%$ of organic compounds, but ammonium nitrogen remained. Both methods (TRE) did not decrease toxicity to the nitrifying microorganisms. We have concluded that ammonium nitrogen and organic substances do not contribute much to the toxicity of the leachate. Further work will be focused on some other TRE methods, mainly ion exchange to assess the contribution of high concentrations of inorganic compounds.
\end{abstract}

Keywords: toxicity reduction evaluation, landfill leached, air-stripping, powdered activated carbon treatment. 


\section{Introduction}

Currently, deposition on landfill is the most widely used method for municipal solid waste disposal. Leachate emissions from landfill sites are of concern, primarily due to their toxic impact when released untreated into the environment (Sormunen et al [1]; Salem et al [2]). Landfill waste is comprised of a wide range of inorganic, organic and/or xenobiotic compounds, which affects the composition and environmental potential of formed leachate. Its composition is therefore site and time specific, based on the characteristics of deposited solid wastes, physico-chemical conditions, rainfall that regulates moisture level and landfill age. Even within the single landfill site variability is frequently evident. Significant components of leachate are heavy metals and degradable organics at the beginning of landfill operation, while persistent organic pollutants usually appear later as a result of biotic and abiotic processes in the system (Robinson [3]; Renou et al [4]).

Among these substances are several compounds classified as potential hazardous: bioaccumulative, toxic, genotoxic with possible endocrine disruptive effects. The leachate should be collected and treated properly to avoid widespread contamination of the receiving environment and to meet regulatory demands (Pivato and Gaspari [5]; Sang and Li [6]). If this final effluent is unacceptably toxic, a comprehensive program to reduce the toxicity must be started. Such a program typically includes a sequence of steps: firstly measurement of the toxicity and then fine-tuning the operation of the existing treatment facility (Lankford and Eckenfelder [7]). Following toxicity reduction and evaluation (TRE) procedures in the plant three kinds of activities are simultaneously used: implementation of "best management practices", evaluation of individual-source treatment technologies and upgrading the existing wastewater treatment system.

To assist dischargers in evaluating the toxicity, U.S. EPA has published a document on toxicity identification procedures for effluents EPA [8]. TRE is defined as a stepwise process and combines toxicity testing and analyses of the physical and chemical characteristics of effluents to identify toxicants. Because TRE is conducted in a tiered approach, judgement is required in selecting the appropriate steps for characterising the causative toxicants and for evaluating options for controlling effluent toxicity. Toxicity tests by their nature provide useful information about an important property of an effluent but do not, however, identify the causative agents responsible for toxicity. Within recent years, several protocols have been developed for isolating and identifying toxic components in complex waste mixtures (Ford [9], Coombe et al [10]; Isidori et al [11]; Jo et al [12]). Our approach for the identification of toxic effluent fractions is based on the principal of sequential removal of chemical fractions coupled with the toxicity test. We identified key toxic components in the landfill leachate by fractionation of samples through chemical and physical means (air stripping and adsorption on activated carbon). 


\section{Materials and methods}

\subsection{Description of the landfill}

The investigated landfill leachates were collected at Ljubljana landfill, which is situated south of Ljubljana city (350,000 inhabitants). It is used for the disposal of non-hazardous wastes. It was designed applying all requirements to protect the environment. It has an underlying membrane, gas and leachate collection system and complete monitoring of gas and leachate emissions. The old part of the landfill has been used since 1964 and it was closed in 1987. It lies over 47.5 hectare, it was covered by soil and planted with poplars to reduce formation of leachates. Leachates are still collected in a equalization basin, some minor portion of them are also treated in near-by wetland system. This raw untreated leachate was used as mature one in our experiments. The second sample (fresh leachate) was collected from the equalization basin of the new part of the landfill. Its construction started in 1987 and it covers 41.5 hectare. It has five fields, which are being filled gradually with wastes. On the first three $3,000,000$ $\mathrm{m}^{3}$ of wastes have been deposited until 2003 and covered by soil. The wastes are now deposited in fourth field, while the leachates are collected by common system for all five fields. Their quality is regularly monitored and they are released into sewage system and treated jointly with other municipal wastewaters in Ljubljana city treatment plant (Primožič [13]).

\subsection{The TRE procedure}

The fractionated methods applied to samples were air stripping and adsorption on PAC. Air-stripping removes volatile and $\mathrm{pH}$ extractable organic chemicals as well as some inorganic chemicals (e.g. hydrogen sulfide and ammonia). Shifting the $\mathrm{pH}$ alters the form of some chemicals, making them less ionic and hence more likely to air-strip. False results in terms of the true mechanism of removal can sometimes be obtained if chemicals are precipitated at high $\mathrm{pH}$ and do not return to their original form following $\mathrm{pH}$ re-adjustment, or if rearation is oxidising rather then stripping the toxicants. Powdered activated carbon (PAC) removes chemicals by adsorption, pore entrapment and, ion exchange (in the case of metals). PAC treatments are designed to remove adsorbable chemicals, but remove a wide variety of chemicals due to different mechanisms. PAC treatments are often successful, but relatively non selective.

\subsubsection{Air stripping}

The $1000 \mathrm{ml}$ samples, previously adjusted to $\mathrm{pH} 11$ and an original sample were exposed, during continuous mixing, to 24 hours of aeration with aquarium pumps $\left(Q_{a i r}=120 \mathrm{~L}\right.$ per hour. The samples were chemically analysed followed by neutralisation and toxicity analyses.

\subsubsection{Adsorption on PAC}

Aliquots of $1 \mathrm{~L}$ of samples were exposed to $0.5,5.0,10.0 \mathrm{~g}$ and 50.0 of activated carbon (GAC, DARCO, 20-40 MESH), during continuous stirring for 24 hours 
at $20{ }^{\circ} \mathrm{C}$. The treated samples, after filtering through $0.45 \mu \mathrm{m}$ pore filter were chemically and toxicologically investigated.

\subsection{Chemical and toxicity analyses}

Analytical control of leachates characterization and monitoring of treatment efficiency included $\mathrm{pH}, \mathrm{BOD}_{5}$ (Biochemical Oxygen Demand) (ISO 5815 [14]), COD (Chemical Oxygen Demand) (ISO 6060 [15]), DOC (Dissolved Organic Carbon) (Shimadzu TOC 5000A Analyzer, ISO 8245 [16]), and nitrogen as ammonium (ISO 7150/1 [17]). Phosphate, nitrate and chloride were determined by chemically suppressed ion chromatography (DIONEX 4000) in the filtered samples using a $0.2 \mu \mathrm{m}$ filter (ISO 10304-2 [18]). To determine the toxicity of raw landfill leachate and its toxicity after fractionated procedure, we performed two acute toxicity tests i) measurement of inhibition of bioluminescence with freeze-dried luminescent bacteria Vibrio fischeri (DR. LANGE LUMIStox, ISO 11348-2 [19]) and measurement of inhibition of nitrification of activated sludge (ISO 9509 [20]).

\section{Results and discussion}

In the Table 1 composition of the raw leachate is presented.

Table 1: $\quad$ Physico-chemical analysis of the raw landfill leachate.

\begin{tabular}{|l|c|c|}
\hline & $\begin{array}{c}\text { Landfill leachate (average } \\
\text { value } \pm \mathrm{SD})\end{array}$ & Limits value \\
\hline $\mathrm{pH}$ & 8.4 & $6.5-9.0$ \\
\hline $\mathrm{COD}, \mathrm{mgL}^{-1}$ & $2555 \pm 221$ & 300 \\
\hline $\mathrm{BOD}_{5} \mathrm{mgL}^{-1}$ & $91 \pm 5$ & 30 \\
\hline $\mathrm{DOC}, \mathrm{mgL}^{-1}$ & $700 \pm 14$ & $/$ \\
\hline $\mathrm{IC}^{\mathrm{mgL}}{ }^{-1}$ & $910 \pm 18$ & $/$ \\
\hline $\mathrm{PO}_{4}{ }^{3-}-\mathrm{P}, \mathrm{mgL}^{-1}$ & $14.3 \pm 0.2$ & 50 \\
\hline $\mathrm{NH}_{4}{ }^{+}-\mathrm{N}, \mathrm{mgL}^{-1}$ & $1337 \pm 0.2$ & $/$ \\
\hline $\mathrm{Norganic}_{\mathrm{mgL}} \mathrm{mg}^{-1}$ & $870 \pm 43$ & 35 \\
\hline $\mathrm{NO}_{3}{ }^{-}-\mathrm{N}, \mathrm{mgL}^{-1}$ & $2.3 \pm 0.1$ & $*$ \\
\hline $\mathrm{Cl}^{-}, \mathrm{mg} \cdot \mathrm{L}^{-1}$ & $1020 \pm 80$ & \\
\hline
\end{tabular}

/ Not defined.

* Limit value is defined according to toxicity to Daphnia magna.

In comparing physico-chemical data on monitored it can be seen, that Slovenian effluent limits for release of the leachates into the surface waters are exceeded (Official Gazette [21]). Leachates could not be released into the environment without appropriate treatment. This was also confirmed by toxicity testing indicating high toxicity of the leachate to both types of investigated 
organisms (Table 2). Leachate was the most toxic to nitrifying organisms of activated sludge.

Table 2: $\quad$ Toxicity of the raw landfill leachate.

\begin{tabular}{|l|l|c|}
\hline \multicolumn{1}{|c|}{ Toxicity test } & \multicolumn{1}{|c|}{ Parameter } & Value \\
\hline \multirow{5}{*}{ Vibrio fischeri } & $\begin{array}{l}30 \operatorname{minEC}_{20}, \\
\text { Vol.\% }\end{array}$ & 4.8 \\
\cline { 2 - 3 } & $30 \mathrm{minEC}_{50}, \mathrm{Vol}_{0} \%$ & 14.1 \\
\cline { 2 - 3 } & $30 \mathrm{minEC}_{90}, \mathrm{Vol}_{\mathrm{y}} \%$ & 58.9 \\
\hline $\begin{array}{l}\text { Inhibition } \\
\text { nitrification }\end{array}$ & $\begin{array}{l}180 \mathrm{minEC}_{50} \\
(\mathrm{Vol} . \%)\end{array}$ & 0.1 \\
\hline
\end{tabular}

We identified key toxic components in the landfill leachate through fractionation of samples with chemical and physical means (air stripping and adsorption on PAC). The goal of each fractionation step was to reduce the toxicity due to specific group of chemicals (organic pollution and ammonia nitrogen) and compare the results to the toxicity present in the unaltered sample. The most effective procedures for the removal of pollution were air stripping at $\mathrm{pH} 11$, and adsorption on PAC at a concentration of $50 \mathrm{~g} \mathrm{~L}^{-1}$. The results of toxicity reduction are presented in Figure 1 and Figure 2.

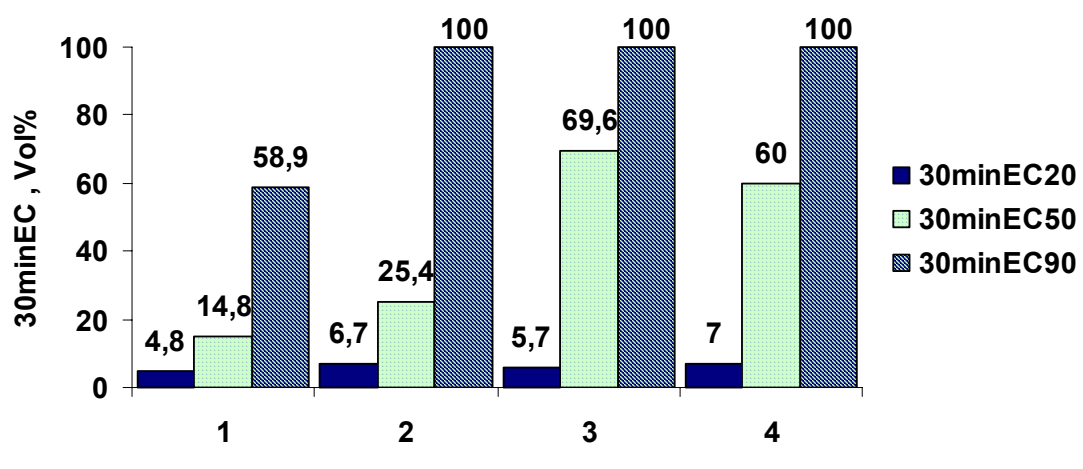

Fractionated procedures

Figure 1: Relative effectiveness of fractionated procedures in toxicity removal towards Vibrio fischeri (1-untreated sample; 2-air stripping at $\mathrm{pH} 11 ; 3$-adsorption on $\mathrm{PAC}$ at a concentration of $10 \mathrm{~g} \mathrm{~L}^{-1}$; 4-adsorption on PAC at a concentration of $50 \mathrm{~g} \mathrm{~L}^{-1}$ ). 


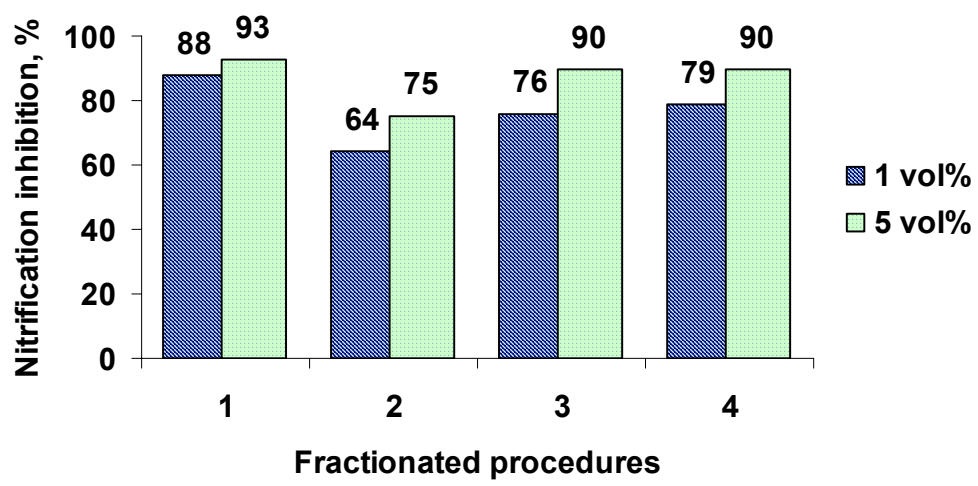

Figure 2: Relative effectiveness of fractionation techniques in toxicity removal towards nitrification (1-untreated sample; 2-air stripping at $\mathrm{pH} 11 ; 3$-adsorption on $\mathrm{PAC}$ at a concentration of $10 \mathrm{~g} \mathrm{~L}^{-1}$; 4-adsorption on PAC at a concentration of $50 \mathrm{~g} \mathrm{~L}^{-1}$ ).

\subsection{Air stripping}

To remove ammonia, landfill leachate was vigorously air-stripped at $\mathrm{pH} 11$ and at the original $\mathrm{pH}$. Shifting the $\mathrm{pH}$ alters the form of some chemicals, making them less ionic and hence more likely to air-strip. The results of time-dependent reduction of the ammonia concentration are presented on Figure 3.

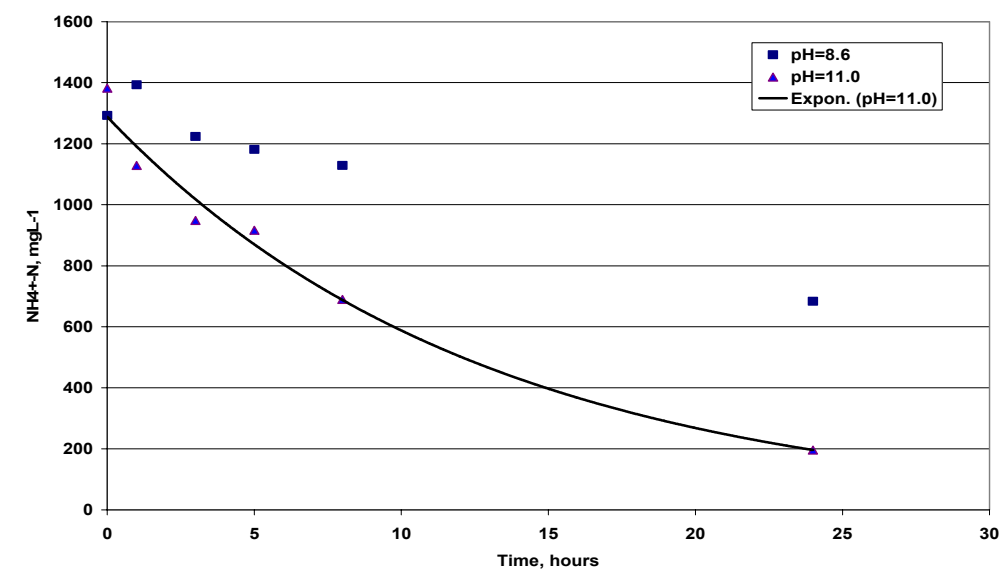

Figure 3: Impact of aeration time and $\mathrm{pH}$ on ammonia removal from landfill leachate. The solid line represents a non-linear regression fit to $\mathrm{y}=1287.8 \mathrm{e}^{-0.078 \mathrm{x}}$ with $\mathrm{R}^{2}=0.99$. 


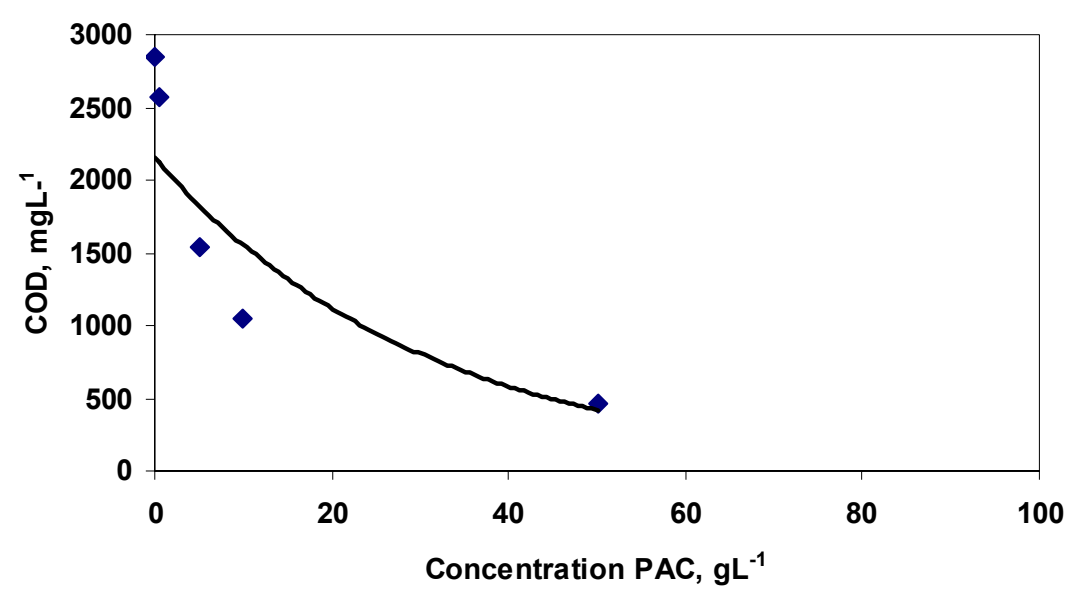

Figure 4: COD removal in batch treatment of landfill leached with PAC. The solid line represents a non-linear regression fit to $y=2155 \mathrm{e}^{-0.0328 \mathrm{x}}$ with $\mathrm{R}^{2}=0.86$.

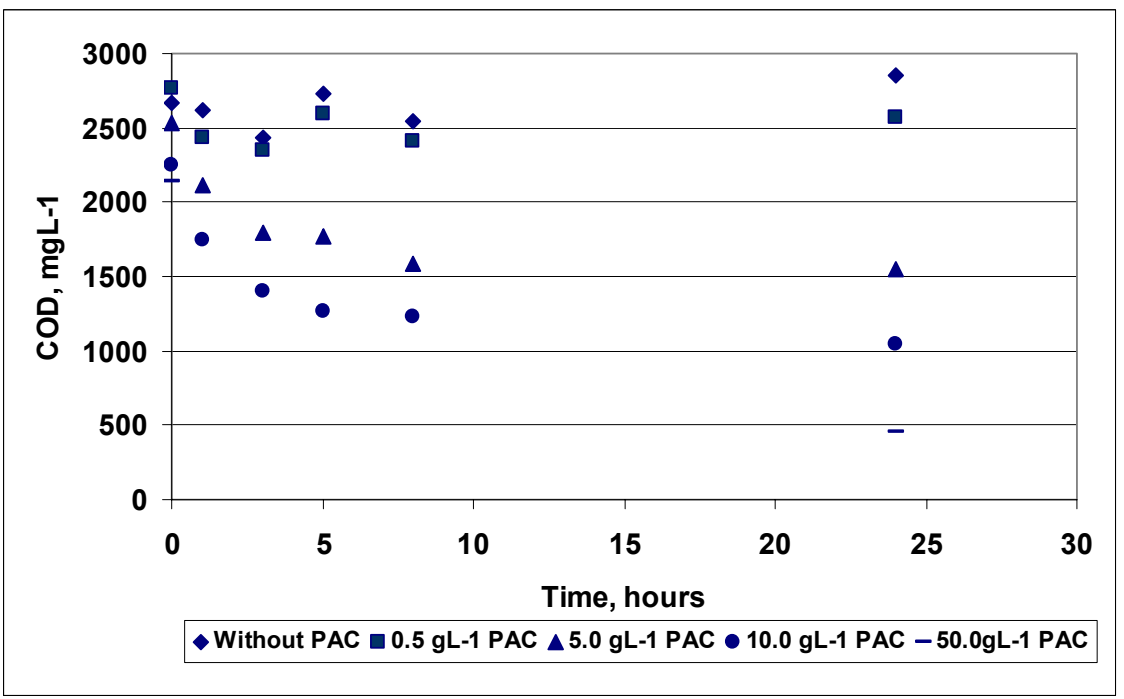

Figure 5: Impact of time and PAC concentration on COD removal from landfill leachate.

The air-stripping at $\mathrm{pH} 11$ was most successful for removing ammonia nitrogen from the treated sample. In the 24 hours stripping experiment $85 \%$ of ammonia nitrogen was removed. During the operation we checked the comparable for neutral and basic $\mathrm{pH}$. Some reduction of toxicity can be achieved through stripping of volatile organic compounds, although most toxic 
compounds are non-volatile and are not removed. The samples of wastewater were less toxic for both organisms used in our study, as we can see from Figure 1 and Figure 2, but ammonia does not have a significant effect on the toxicity of landfill leached organic load is still present.

\subsection{Adsorption on PAC}

Using activated carbon can reduce wastewater toxicity. Activated carbon typically has a greater affinity for adsorbing high molecular-weight compounds, which are also usually more toxic than smaller, easily biodegradable compounds. Adsorption of organics on carbon depends on a number of factors, such as molecular weight, solubility, polarity, location of functional group and overall molecular configuration. The results of COD removal are presented in Figure 4.

As we can see from Figure 4 and Figure 5, PAC was very effective for removing organic compounds expressed as COD (79\%). Additionally we removed $35 \%$ of ammonia nitrogen in the sample treated with PAC at concentration of $50 \mathrm{~g} \mathrm{~L}^{-1}$. Treatment on PAC was the most effective procedure for the toxicity reduction for Vibrio fisheri as we can see from Figure 1.

\section{Conclusions}

Municipal landfill leachates typically contain high ammonium and chloride concentrations, as well as high level of organics, many of them also toxic and resistant to biodegradation. Because of that, treatment efficiency of conventional biological plant for landfill leachates is usually very low. The purpose of our research work was to evaluate the quality of the leachate originated from municipal landfill and to assess efficiency of air stripping and adsorption to the activated carbon for reduction of toxicity of the leachate. Both fractionated procedures were used to identify the contribution of organic substances (air stripping, adsorption) and ammonium nitrogen (air stripping) to toxicity of the effluent. We have compared physico-chemical analysis and toxicity of the leachate before and after TRE procedures. Air stripping removed $85 \%$ of ammonium nitrogen at $\mathrm{pH}$ value of 11 , but the removal of organics was low. On the other hand, adsorption to activated carbon $\left(50 \mathrm{~g} \cdot \mathrm{L}^{-1}\right)$ removed $79 \%$ of organic compounds, but ammonium nitrogen remained. Both methods (TRE) did not decrease toxicity of the leachate significantly. We have concluded that ammonium nitrogen and organic substances do not contribute much to the toxicity of the leachate. Further work will be focused on some other TRE methods, mainly ion exchange to assess the contribution of high concentration of inorganic compounds

\section{References}

[1] Sormunen, K., Einola, J., Ettala, M. \& Rintala, J., Leachate and gaseous emissions from initial phases of landfilling mechanically and 
mechanically-biologically treated municipal solid waste residuals, Bioresource Technology, 99(7), pp 2399-2409, 2008.

[2] Salem, Z., Hamouri, K., Djemaa R., \& Allia, K., Evaluation of landfill leachate pollution and treatment, Desalination, 220(1-3), pp 108-114, 2008.

[3] Robinson, A.H., Landfill leachate treatment, Membrane Technology, 2005(6), pp 6-12, 2005.

[4] Renou, S., Givaudan, J.G., Poulain, S., Dirassouyan, F. \& Moulin, P., Landfill leachate treatment: Review and opportunity, Journal of Hazardous Materials, 150( 3), pp 468-493, 2008.

[5] Pivato, A., \& Gaspari, L., Acute toxicity test of leachates from traditional and sustainable landfills using luminescent bacteria, Waste Management, 26 (10), pp. 1148-1155, 2006.

[6] Sang, N., \& Li, G., Genotoxicity of municipal landfill leachate on root tips of Vicia faba, Mutation Research/Genetic Toxicology and Environmental Mutagenesi, 560(2), pp 159-165, 2004.

[7] Lankford, P., \& Eckenfelder, W. W., Toxicity Reduction in Industrial Effluents. Van Nostrand Reinhold, New York, 1990.

[8] EPA, Generalized Methodology for Conducting Industrial Toxicity Reduction Evaluations (TREs), EPA. Ohio, 1989.

[9] Ford D.L., Toxicity Reduction Evaluation and Control Techomic Publishing Company, Lancaster, 1992.

[10] Coombe,V.T., Moore, K. W., \& Hutchings, M. J., TIE and TRE: An abbreviated guide to dealing with toxicity, Water Science and Technology, 39(10-11), pp 91-97, 1999.

[11] Isidori, M., Lavorgna, M., Nardelli., \& Parrella, A., Toxicity identification evaluation of leachates from municipal solid waste landfills: a multispecies approach, Chemosphere, 52(1), pp 85-94, 2003.

[12] Jo, H.J., Park, E. J., Cho, K., Kim, E.H., \& Jung; J., Toxicity identification and reduction of wastewaters from a pigment manufacturing factory, Chemosphere, 70(6), pp 949-957, 2008.

[13] Primožič, P., Treatment of landfill leachates at landfill Barje, Diploma thesis, University of Maribor, Faculty of Chemistry and Chemical Technology, Maribor, 2006 (In Slovene).

[14] ISO 5815, 2003, Water Quality-Determination of biochemical oxygen demand after $\mathrm{n}$ days $\left(\mathrm{BOD}_{\mathrm{n}}\right)$ - Part 1: Dilution and seeding method with allylthiourea addition.

[15] ISO 6060, 1989, Water Quality-Determination of the chemical oxygen demand.

[16] ISO 8245, 1999, Water Quality-Guidelines for the determination of total organic carbon (TOC) and dissolved organic carbon (DOC).

[17] ISO 7150/1, 1984, Water Quality-Determination of ammonium-Part 1: Manual spectrometric method.

[18] EN ISO 10304-2, 1996 Water Quality-Determination of bromide, chloride, phosphate and sulphate by ion chromatography. 
126 Environmental Toxicology II

[19] ISO 11348-2, 1998, Water Quality-Determination of the inhibitory effect of water samples on the light emission of Vibrio fischeri (Luminescent bacteria test)-Part 2.

[20] ISO 9509, 1989, Water Quality-Method for assessing the inhibition of nitrification of activated sludge micro-organisms by chemicals and waste waters.

[21] Official Gazette of the Republic of Slovenia, 2000, Decree on emissions of leachates from solid waste landfills, UL RS 7/2000, 944 (in Slovene) 